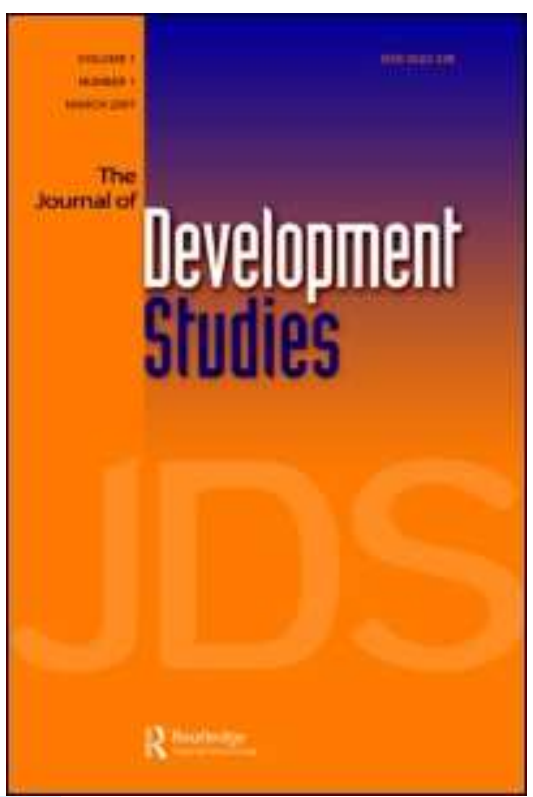

\title{
Determinants of Remittances: The Case of the South Asian Community in Manchester
}

\begin{tabular}{|r|l|}
\hline Journal: & Journal of Development Studies \\
\hline Manuscript ID: & FJDS-2009-Jun-0036.R3 \\
\hline Manuscript Type: & Original Manuscripts \\
\hline Keywords: & $\begin{array}{l}\text { Economic development < Economics, Development < Social Issues, } \\
\text { Ethnic minorities < Social Issues }\end{array}$ \\
\hline \multicolumn{2}{|l}{} \\
\hline
\end{tabular}

\section{SCHOLARONE \\ Manuscripts}




\title{
Third Revised Paper
}

July 20, 2010

\section{Determinants of Remittances: The Case of the \\ South Asian Community in Manchester}

\author{
Word Count: 7838 \\ (Including text, tables, endnotes and references)
}

\begin{abstract}
This paper investigates the remittance behaviour of the South Asian community using new data from Indian, Pakistani and Bangladeshi households in Manchester. The findings show that standard variables such as income, employment, education, linkages to the home country and host country are important determinants of remittances. Although remittances are sent mainly for consumption purposes, those sent for land acquisition and savings have stronger association with the amount of remittances. In addition, we find strong evidence for the remittance decay hypothesis for Indian and Pakistani migrants, but not for Bangladeshi migrants.
\end{abstract}

JEL Classification: E21; F22; C25; D10.

Keywords: remittances; international migration; household data; Manchester. 


\section{Introduction}

Recent debates on development finance have drawn attention to the role of remittances in achieving the MDGs (Millennium Development Goals) target of fostering growth and alleviating poverty in developing and less developed countries. Recent estimates suggest that a 10 percent increase in remittances as a percentage of GDP can decrease the poverty gap in Asian countries by about 0.71.4 percent (Vargas-Silva et al., 2009). In addition to their role in development, remittances have become a source of concern since $9 / 11$ because of the possibility that, when sent through informal channels as they often are, they could be used to finance terrorism and money laundering. According to Sander (2003), in 2002 the estimated amount of informal remittances to developing countries was between 25 and 125 percent of official remittances. Although these developments have prompted academic research on remittances, there are only a few studies on the determinants of the remittances of the South Asian community in the UK, one of the largest migrant groups both in the UK and worldwide. Thus, this study aims to contribute to the literature by providing an indepth statistical and econometric analysis of the remittances of three major South Asian communities of Indian, Pakistani and Bangladeshi origins in Manchester using a new, comprehensive household database. ${ }^{1}$

The South Asian community is well established both professionally and politically in the United States and Western Europe. The immigration of South Asian people to the UK started in the colonial period and continued after independence. The expulsion of Indian communities from East Africa also contributed to the strong presence of the South Asian population in the UK. The migration from Pakistan and Bangladesh was male-led with many migrants coming from poor rural areas such as Mirpur and Syllhet, and settling in the industrial areas of North West England as well 
as parts of London (Dale, 2008). The official remittance inflows to South Asia have increased continuously over the past decade from $\$ 5.6$ billion (1.4\% of GDP) in 1990 to $\$ 43.8$ billion (3.2 percent of GDP) in 2007 (World Bank, 2008). In 2007, the top recipient countries of recorded remittances in South Asia were India (\$27.0 billion), Bangladesh (\$6.4 billion) and Pakistan (\$6.1 billion), collectively making the South Asia region the third largest regional recipient of remittances in the world (World Bank, 2008). According to a recent survey by DFID (2006), a typical South Asian family in the UK sent an average of over $£ 1,000$ back home, and South Asian countries are among the five largest recipients of remittances from the UK.

Notwithstanding their significant presence in the UK, only Clark and Drinkwater (2007) provides an econometric analysis of the determinants of the remittances of the South Asian community, and only a few studies, such as Ballard (2003), Seddon (2004), Boon (2006), provide some information about their socio-economic background and remittances. Clark and Drinkwater (2007) use nationwide household data to examine the remittance incidence of the major migrant groups in the UK, including the Pakistani, Indian and Bangladeshi communities. According to the findings of Clark and Drinkwater (2007) income is the main determinant of the remittance incidence of all three South Asian communities, Pakistani migrants are most likely to send remittances, and years since migration and education do not have a significant effect on the remittance incidence, although having foreign qualifications promotes the remittance incidence of Indian community. Different from Clark and Drinkwater (2007), we use household data from Manchester, examine the amount of remittances, instead of remittance incidence, and incorporate the use of remittances into our econometric model. In line with Clark and Drinkwater (2007), our findings show that income is the main determinant of the amount of remittances, and Pakistani migrants send the largest amount of 
remittances. However, in our model education has a positive and years since migration has a negative impact on the amount of remittances of South Asian community. Furthermore, our results reveal that the remittances sent for savings and land acquisition tend to be larger than those sent for consumption and loan payments.

The rest of this paper is structured as follows. The next section reviews the theoretical and empirical background of the determinants of remittances; section three provides information on data and methodology; section four presents the recent trends in the socio-economic background and remittance profile of three South Asian communities in Manchester; section five reports the findings of econometric analysis; and section six concludes.

\section{Determinants of Remittances - Theory and Evidence}

Broadly, the main theories on remittances fall into three categories: altruism, self-interest, and intertemporal contractual agreement. The last category includes all kinds of contractual arrangements between the migrant and the household left behind, such as insurance and risk sharing, exchange, and implicit loan agreements. Self-interested remittances generally arise from the desire to secure an inheritance, fixed assets or income from one's parents, or to obtain social or financial services from relatives. Purely altruistic remittances involve transfers to the home country to aid the recipient without any expectation of reciprocity. As Lucas and Stark (1985) point out, 'altruistic' remittances often include an element of self-interest and so may be better regarded as tempered altruism or enlightened self-interest. In other cases, altruistic remittances may be accompanied by an element of contractual agreement. 


\begin{abstract}
Altruistic remittance behaviour, first identified by Johnson and Whitelaw (1974), involves a set of factors that determines remittance behaviour irrespective of the economic situation of the migrants. In many cultures and religions, selfless concern for the welfare of others is paramount, which is different from moral obligations. Specifically, migrants care about the well-being of their family because their utility function embodies the utility function of their family members (Agarwal and Horowitz, 2002). The main indicators of altruistic remittances cited in Funkhouser (1995) are that remittances are inversely related to the recipient's income; they tend to decrease with the number of other migrants from the same family and decrease with the time spent in the host country.
\end{abstract}

Contractual agreement basically refers to mutual agreement between the migrant and his/her family that they will help each other in difficult times (for example, insurance and risk sharing) and that the migrant will at some point pay back the costs of education and migration incurred by his/her family (implicit loan agreement). Lucas and Stark (1985) explain the implicit contractual arrangement between the migrant and the home country household as being based on investment and risk. The notion of risk sharing appears to be self-enforcing and cooperative (Agarwal and Horowitz, 2002), and arises from both self-interest and mutually beneficial arrangements (Lianos, 1997). In the case of an implicit loan agreement, the migrant repays the family's human capital investment either in cash or by financing other migrant family numbers (Poirine, 1997). Selfinterested remittance is mainly associated with the exchange motive put forward by Rapoport and Docquier (2005). This explains the remittance behaviour as being driven by the migrants' intention to return home. However, exchange motivation can also take place within the mutual contractual agreement. 


\begin{abstract}
Although the motivational models provide a structured framework to explain the remittance behaviour of migrants, they are unlikely to provide a holistic picture of this complex issue since many other factors can influence migrants' decisions to transfer remittances to their home country. For instance, Lianos (1997) argues that remittance behaviour can be the result of a complex decision-making framework of a migrant seeking to maximise his/her economic welfare through various rational behaviours. The argument here is that migrants' savings and investment behaviours and the flow of remittances are somewhat difficult to predict because of the many different possible objectives of the migrant, which might include permanent settlement in the home country, minimising the time to be spent in the home country, or maximising wealth within a specific period of time.
\end{abstract}

The nature and patterns of various economic and social factors appear to play a crucial role in determining the size of remittances. Sander (2003) specifies several factors such as the migrant's profile and salary level, the cost of living in the host country, political and economic volatility in the home country, the migration period, and generational patterns. Based on a review of various empirical studies, Rapoport and Docquier (2005) conclude that familial inter-temporal contracts appear to have more explanatory power than individualistic considerations. Even though some individualistic considerations such as altruism, an intention to return, and inheritance prospects may explain remittance behaviour, their influence generally takes place within a familial context.

In accordance with the theoretical predictions of altruism and mutual contractual agreement, Osili (2001) finds that the remittances of Nigerian migrants in the US are determined by altruism, as the 
richer families tend to receive lower amount of remittances. Clark and Drinkwater (2007) show that the stronger family ties and the repayment of contributions received earlier by the migrant are significant drivers of the remittances of migrants in the UK, as they are more likely to remit than their native-born counterparts. Glytsos (1997) put forward that the remittance behaviour of temporary migrants is driven by an obligation to meet the needs of close family back home coupled with an endogenous decision-making process by which the migrant's own higher consumption is postponed for future comfort at home after an early return.

\section{Data and Methodology}

Data for this analysis was collected mainly through random sampling strategy from 700 Indian, Pakistani and Bangladeshi households in the districts of the City of Manchester that hold the largest South Asian communities in Manchester. According to 2001 census data, among all minorities, Pakistanis and Indians constitute the largest share of the total population of Manchester followed by Chinese and Bangladeshis, 5.9, 1.5, 1.3 and 0.9 percent respectively, (Manchester City Council, 2001). The largest concentration of these three communities is in Longsight constituting 41 percent of Longsight's total population, followed by Cheetham (30\%), Whalley Range (26\%), and Rusholme (24\%), Levenshulme (17\%), Crumpsall (14\%), Fallowfield (12\%) and Withington (10\%). Our data covers the first four wards where the majority of South Asians reside and Withington, which together hold half of all three communities in Manchester (see Table 1).

Face to face interviews were carried out with individuals of Indian, Pakistani and Bangladeshi origins, who were approached in ordinary public places such as streets, shops, parks, in front of 
houses, offices, community-based organisations, mosques, cafes, bus stops, and where possible in houses. We are aware that this strategy might lead to under-representation of some groups such as females and the elderly. However, given the high rate of non-response from the households in their residency, it was not possible to conduct interviews in pre-assigned residencies, as true random sampling strategy requires. Nonetheless, to cover the main parts of a ward, prior to the interviews we identified all the main streets and public places in each ward with a high concentration of the South Asian community. In addition, to make sure that each South Asian group was fairly represented, all three communities are over sampled and the number of interviews is determined in line with the relative size of each community in the wards (Table 1).

\begin{abstract}
Although we mostly followed random sampling strategy, in very few cases, leads from other interviewees were used to find the areas of a ward with high concentrations of a particular South Asian community to reach our target number from each group. This was necessary because even though these three groups tend to work or reside in the same areas in the dynamic parts of the wards, which we first covered without any difficulty, in other parts local knowledge was necessary to find out the whereabouts of those individuals from each group.
\end{abstract}

A final point about our methodology concerns the fact that we interviewed only those respondents sending remittances, as the central focus of the study is to examine the determinants of the amount of remittances and our funding was not sufficient to cover both remitters and non-remitters. We understand that employing such a strategy might cause sample selection bias. However, many studies examining the determinants of remittances have employed a similar strategy (i.e. Knowles and Anker, 1981; Blue, 2004; and Durand et al., 1996). As explained in Knowles and Anker (1981), 
including non-remitters in the analysis could cause bias in the estimations towards zero if the majority of the migrants are non-remitters. In addition, our data include any amount of remittances that is different from zero, i.e. annual remittances in our data are as low as $£ 100$. Thus the sample selection bias could easily be corrected by employing Tobit analysis which censors the remittances data at a lower level of remittance amount. ${ }^{2}$

Next, we compare the descriptive statistics of the key variables from our data collected in 2006 with those obtained from 2001 national and local census, in order to assess whether or not our data are representative of the three South Asian communities in Manchester and in the UK. As seen from Table 2, even though almost all statistics from our data are somewhat larger than those from the national and local census, they are entirely consistent with the latter in terms of their relative values across the three South Asian communities. For example, in both our data and census data, Indian migrants have the highest income, followed by Pakistani and Bangladeshi migrants, while Pakistani migrants send the largest amount of remittances, send them more regularly, and are more likely to remit to their parents.

The age, religious background, and the fraction of each group in self-employment, owning a house in the UK, and sending remittances to their children, are similar in both sources. Although there are some differences between the two sources with regards to the full-time and part-time employment positions of the three communities, considering that our data is collected five years after the census data reported in Table 2, they are not alarmingly disparate. The only major difference is that our data seem to over-represent the married and highly educated individuals in all three communities compared to the census data, which should be kept in mind when interpreting the findings. In fact, 
these differences alone could explain the higher income and remittance levels of the three communities compared to those from the national census.

On the whole, our data deviates slightly from census data, and in almost all cases it overestimates the statistics by about a third in relation to the census data, meaning that there will not be a serious bias in the regression analysis. In addition, our data is fully in line with the census data in terms of the relative values of the key variables across the three South Asian communities, implying that the comparative statistical analysis in our paper can largely be representative of these three groups. Finally, since this is the only data providing methodical information about the remittances of the three major South Asian communities in Manchester, we strongly believe that it will contribute greatly to our understanding of the remittance behaviour of these groups, which have significant presence in the UK.

\section{Socio-Economic Characteristics and Remittance Patterns of the South Asian Community in Manchester}

This section provides an overview of the social, economic and demographic characteristics of the South Asian community in Manchester as well as their remittance patterns. The summary statistics and the frequencies of the main indicators for the full sample are reported in Table 3. As the table shows, the average age of a respondent is 37; 68 percent are married, and 84 percent of the married respondents have their spouses in the UK (Table 3). ${ }^{3}$ Given that Pakistani and Bangladeshi migrants constitute the largest portion of our data, it is not surprising that 74 percent of all respondents are Muslims, followed by Hindus (26\%). 84 percent of all respondents work full time 
(in full-time employment or self-employment), 37 percent are UK citizens, 25 percent are permanent residents, 26 percent are on a work permit visa or highly skilled migration programme, and 27 percent are on a student visa. The average time of residency in the UK is 12 years, and 31 percent intend to return to their home country. In addition, 65 percent of all respondents use informal channels to send remittances, providing support for the view that the majority of the South Asian migrants use informal channels, named as hawala or hindu, for money transfers.

As seen from Table 3, on average, a South Asian individual in Manchester in our data has a university degree, earns $£ 1,378$ per month gross, and remits $£ 1,672$ a year. In addition, 42 percent of respondents own their accommodation, 88 percent have fixed assets in their home country and the parents of 18 percent of the respondents live in the UK. In terms of the characteristics of recipients, we find that the average monthly income is $£ 238$, and the main recipient groups are the parents of the remitters (59\% sent money to their parents) followed by siblings (28\%), cousins/aunts/uncles (20\%), spouse/children (11\%) and close family friends (8\%). The most common use of remittances is to finance consumption, followed by savings, education, land acquisition and loan payment.

To examine the differences in terms of the key social, economic and demographic indicators across Pakistani, Indian and Bangladeshi communities, we also report the statistics for each group in Table 4. As observed, Indian respondents have the highest monthly income $(£ 1,784)$ followed by Bangladeshi and Pakistani migrants, $£ 1,286$ and $£ 1,206$, respectively; while Pakistani migrants send the largest amount of remittances $(£ 1,817)$, followed by Indian and Bangladeshi migrants ( $£ 1,559$ and $£ 1,486$, respectively). The average age and education levels of respondents are close 
across the three communities, although Indians have marginally higher levels of education. A closer look at Table 4 reveals that the Bangladeshi community is the most established South Asian community in Manchester in that a larger proportion of Bangladeshis has UK citizenship, own their house, and have their parents in the UK. They also have more siblings and children in the UK and have been residing in the UK much longer than the migrants in the other two communities. In all communities, parents seem to be the main recipients of the remittances, and the remittances of all three communities are used mainly for consumption followed by savings.

Since the remittances literature indicates differences between temporary and permanent migrants' remittances (i.e. Dustmann and Mestres, 2010; Ulku, 2010; 2004; Glytsos, 1997), in Table 5 we also present the data for permanent and temporary migrants separately. ${ }^{4}$ As seen from the table, there are differences between these two groups in terms of their age, income, remittances, education level and the duration of their stay in the UK. On average, temporary migrants seem to be 10 years younger, earn $£ 355$ less, are more educated, have spent 15 years less time in the UK, and send $£ 213$ more remittances than permanent migrants. In addition, a smaller proportion of temporary migrants own their house in the UK and hold a full-time employment position.

Finally, in Figure 1 we report the pattern of remittances against the key variables such as the duration of residence in the UK, age and education level, for the full sample and for the three communities separately. As the figure shows, although the patterns of remittances of the three migrant groups exhibit different trends until about the $28^{\text {th }}$ year of their residence in the UK, they all decline substantially afterwards. We observe a gradual decline in the remittances of Indian and Pakistani migrants throughout the first twenty-eight years, while the remittances of Bangladeshi 
migrants increase during this time. Similarly, remittances of Indian and Pakistani migrants start to decline at about the age of 44 , whereas those of Bangladeshi migrants stay stable until the age of 54, after which they increase sharply. In addition, the relationship between remittances and the level of education is highly positive for both Indian and Pakistani migrants, while it is slightly negative for Bangladeshi migrants.

\begin{abstract}
From the findings of Figure 1, we infer that the remittances of Indian and Pakistani migrants might be influenced by both altruistic and mutual contractual agreement motivations given that their remittances decay with their age and the duration of their residence in the UK, providing evidence for altruistic motivation (Funkhouser, 1995), and increase with education, indicating the presence of mutual contractual agreement motivation (Poirine, 1997). The remittances of Bangladeshi migrants, on the other hand, seem to be motivated mainly by self interest, given that their remittances do not decay throughout the duration of their residence and age, and start to increase after the age of 54, suggesting that they might be sending large amounts of money to invest for their retirement. In addition, their remittances are not highly correlated with their education level, weakening the presence of the contractual agreement motivation.
\end{abstract}

\title{
V. Econometric Analysis of the Determinants of Remittances
}

After providing the analysis of the remittances and socio-economic characteristics of the South Asian community in Manchester based on descriptive statistics, in this section we will examine the determinants of the amount of their remittances using Ordinary Least Squares (OLS) and Seemingly Unrelated Regression (SUR) techniques. OLS is an appropriate estimator given that all 
the key variables in the main regression model are exogenous to the amount of remittances. However, in addition to the main regression, we estimate a model that includes the different end uses of remittances as explanatory variables, which could be endogenous to the amount of remittances. To mitigate the potential endogeneity problem between these variables, we employ SUR analysis in which we simultaneously run six regression equations, consisting of the amount of remittances and their five end uses, namely, consumption, savings, education, land acquisition and loan payments.

We are aware that employing instrumental variable analysis would be the most appropriate technique to control for the endogeneity problem. However, due to lack of appropriate instruments for the different uses of remittances, we employed the SUR technique that controls for the correlations across the error terms of the equations, mitigating the potential endogeneity problem. Our econometric model is based on a standard remittances model as shown below:

$$
\operatorname{Re} m i t \tan c e s_{i}=\alpha_{0}+\beta_{1}^{\prime} X_{1, i}+\beta_{2}^{\prime} X_{2, i}+\beta_{3}^{\prime} X_{3, i}+\beta_{4}^{\prime} X_{4, i}+\beta_{5}^{\prime} X_{5, i}+\lambda_{i}+\varepsilon_{i}
$$

where, $X_{1:}$ standard variables on the demographic and socio-economic characteristics of the household head; $X_{2}$ : rootedness in the $\mathrm{UK} ; X_{3}$ : linkages to home country; $X_{4}$ : recipient households' characteristics; $X_{5}$ : use of remittances; $\lambda$ : district dummies. The regression includes the respondents who are either the head of household or the spouse of the head of the household.

The findings of the regression analyses are reported in Table 6. As the first column of the table shows, most of the standard variables on the socio-economic and demographic characteristics of the 
remitters are significant and have the expected sign. More specifically, income, full-time employment and education are all positive and significant in all regressions, with respective coefficients in the range of $0.60-0.75,0.20-0.30$, and $0.07-0.12$. Although the theoretical impact of education on remittances is ambiguous, as it can affect remittances through different channels, there is extensive empirical evidence for its positive impact on remittances. For example, using comprehensive micro data from surveys of immigrants in eleven major destination countries, Bollard et al. (2009) find strong evidence that education has a positive effect on remittances. Age, being married and being female are not significant. Interestingly, being Muslim and having rural origins are significant in all regressions with a positive sign, implying that the migrants from rural areas and who are Muslims send more remittances than others. An interesting observation from these finding is that, once we control for religion, being from Bangladesh or Pakistan does not have an impact on the amount of remittances.

The second column of Table 6 reports the findings of the analysis, which in addition to the standard variables includes the indicators about the rootedness of the migrants in the UK. As seen from this column, only duration of residence in the UK and having parents in the UK are significant in all regressions, while having a spouse in the UK is significant only in some of the regressions. The remaining variables, such as having permanent migrant status, number of children and siblings in the UK, are not significant in any of the regressions. As expected, having a UK-based spouse and duration of residence in the UK have a negative impact on remittances, which is consistent with the findings of earlier studies such as those by Massey and Basem (1992) and Brown (1997). 
The evidence that the duration of the residence in the UK is negatively related to remittances is consistent with the remittance decay theory, which suggests that the longer the time spent away from the home the weaker will become the social linkages of the migrants to their home country, leading to a decrease in remittances over time. Studies such as those of Stark and Lucas (1985) and Funkhouser (1995) assert a close relationship between remittance decay and remittances motivated by altruism. According to these studies, if migrants are motivated by self-interest or by mutual inter-temporal agreement, remittances will not decrease over time because migrants have a future self-interest in the home country or are tied into an implicit contract with the family. In the case of altruism, however, they generally decline over time, given that the social connectedness weakens as the time spent away from the home country increases. When interpreting these results, we should keep in mind that, although as a whole South Asian migrants' remittances decrease with the duration of their residence, remittances by the Bangladeshi community have a tendency to increase throughout their stay in the UK as shown in Figure 1.

In the third column of Table 6, we add the frequency of visits to the home country as an indicator of the social linkages of the migrants to their home countries. We find that the lower the frequency of the visits to the home country (the negative sign on the coefficient comes from the fact that high numbers refer to low frequency of visits) the smaller the amount of remittances the migrants send back to their countries, implying the importance of social linkages to the home country in the amount of remittances. Column 4 presents the findings of the analysis that includes the nature of the relationship between recipient and remitter in the model. As observed, only the remittances sent to spouse or children are significantly higher. Being parents, siblings or extended family does not have a significant impact on the amount of remittances. Finally, in column 5, we incorporate the 
five different uses of remittances in the regression model, and find that among these five uses, only the remittances sent for savings, land acquisition and loan payments have significant impact on the amount of remittances.

However, because the use of remittances might also be affected by the amount of remittances themselves, for robustness check we also report the findings of SUR analysis that estimates the amount of remittances and all five different uses of remittances simultaneously, to control for the contemporaneous correlations among these six variables. The last column of Table 6 reports the results of the SUR analysis of the amount of remittances. ${ }^{5}$ As seen from the last column, the findings of the SUR analysis are very close to those obtained from the OLS, the only exception being that the use of remittances for consumption becomes significant with a positive sign. Thus we conclude that savings have the strongest association with the amount of remittances, followed by land acquisition, loan payments and consumption, in that order. The use of remittances for education does not seem to be a significant determinant of the amount of remittances.

In addition to the analysis of the full sample, we have estimated the amount of remittances separately for permanent and temporary migrants and for the remitters using informal and formal channels. However, the results of the Chow test revealed no differences between the remittance behaviour of these groups, although there are differences in the income and remittance amounts of temporary and permanent migrants when we do not control for other factors.

To sum up, the findings of the econometric analysis suggest that the standard variables of remittance models such as income, full employment, education, rootedness in the host country and 
close familial and community linkages to the home country, are all important determinants of the amount of remittances of the South Asian community in the UK. Furthermore, among the different areas of the use of remittances, savings seems to have the strongest association with the amount of remittances, followed by land acquisition, loan payments and consumption. From the viewpoint of the motivational models, we can infer that the South Asian community's remittances are influenced by a combination of altruism, mutual contractual agreement and self-interest motivations, given that their remittances decay overtime, and are positively associated with education level of the remitters and the use of remittances for savings, land acquisition and loan payments.

\section{Conclusion}

This paper attempted to analyse the remittance behaviour of the South Asian community residing in Manchester using newly developed household-level data collected from 700 households residing in different districts of Manchester. To the best of our knowledge, this is the second study after Clark and Drinkwater (2007) assessing the remittance behaviour of South Asian community in the UK using econometric analysis.

The analysis of the descriptive statistics revealed that the average South Asian individual in our study holds a university degree, earns about $£ 1,375$ per month sends 10 percent of his or her annual income to the home country, which is higher than those of some other migrant groups, such as Turkish migrants in Germany (Ulku, 2010). Consistent with the UK census data in 2001, we also find that Indian migrants are the highest earners, while the Pakistani migrants send the largest amount of remittances on a more regular basis. In addition, 42 percent of the South Asian 
community in Manchester owns a house in the UK, while 88 percent own fixed assets in their home country.

According to the findings of the econometric analysis, remittances of the South Asian community are primarily determined by income, employment status, education level of the remitter as well as his/her rootedness in the UK and linkages to the home country. These results are somewhat different from those of Clark and Drinkwater (2007) in that they do not find a significant effect of education and rootedness in the UK (measured as years from migration) on the remittance incidence of the South Asian communities. This could be due to the fact that they investigate the remittance incidence while we investigate the size of remittances. Among the different uses of remittances, our results show that savings have the strongest association with the amount of remittances, followed by land acquisition, loan payments and consumption.

Contrary to the previous studies, such as those by Glytsos (1997) and Dustmann and Mestres (2010), we find no difference in the remittance behaviour of temporary and permanent South Asian migrants, though temporary migrants tend to earn less and send more remittances than do permanent migrants. Similarly, there is no difference between the remittance behaviour of informal and formal remitters. Finally, remittances of the South Asian community in Manchester seem to be driven by a mix of altruistic, inter-temporal contractual agreements and self-interest motivations, in that their remittances decay overtime, are used mainly for consumption, and are positively associated with the education level of the remitter and the use of remittances for savings, land acquisition and loan payments. 
The main implications of our analysis in terms of the potential developmental impacts of the remittances of South Asian migrants in their home countries are that, first, the average amount of remittances and their share in the incomes of the remitters are higher than those of many other migrant groups, making the remittances a significant financial source for development. Second, that the remittances of Bangladeshi migrants do not decrease with the duration of their residency in the UK, increase towards their retirement age, and a significant proportion of their remittances is spent on land acquisition implies that, compared to the other two groups, the remittances of this group might be more effective in promoting development. Finally, although consumption is the main area where remittances are used, remitters seem to send more money for land acquisition, savings and loan payments, implying that they can promote development not only by relaxing liquidity constraints of the poor but also by creating income generating activities through their impact on savings in the home country. However, considering the relative importance of the remittances as a stable source of development finance, the receiving country governments yet to implement significant strategic interventions and formulate appropriate mechanisms to enhance the impact of remittances on growth and development. 
Table 1. Distribution of South Asian Community and Household Surveys in Manchester Metropolitan Area

\begin{tabular}{lccccccc}
\hline & \multicolumn{3}{c}{$\begin{array}{c}\text { Distribution of SA Community in Manchester, 2001 } \\
\text { Census Data (percent of total population) }\end{array}$} & \multicolumn{3}{c}{$\begin{array}{c}\text { Distribution of Household Surveys in } \\
\text { Manchester in 2006 } \\
\text { (percent of total surveys) }\end{array}$} \\
\hline & All Population & Indian & Pakistani & Bangladeshi & Indian & Pakistani & Bangladeshi \\
Cheetham & 13,121 & 2.7 & 27.0 & 0.4 & 21.5 & 29.9 & 14.4 \\
Longsight & 12,249 & 3.0 & 29.7 & 8.1 & 22.5 & 28.2 & 38.6 \\
W.Range & 11,965 & 3.7 & 21.8 & 0.6 & 20.4 & 28.5 & 11.1 \\
Rusholme & 12,275 & 4.2 & 12.7 & 7.5 & 18.3 & 13.2 & 35.9 \\
Withington & 11,201 & 3.1 & 5.9 & 0.9 & 15.7 & 0.3 & 0.0 \\
\hline Manchester Total & 392,799 & 5892 & 23175 & 3535 & 191 & 355 & 153 \\
\hline
\end{tabular}

Source: a/ Manchester City Council derived from 2001 Census CAS Theme Table 3; b/Authors' data and calculations.

Table 2. Comparison of Our Statistics with those from National and Local Government

\begin{tabular}{lcccccc}
\hline & \multicolumn{2}{c}{ National and Local Government Data } & \multicolumn{3}{c}{ Our Data } \\
\hline \multicolumn{1}{c}{ Variables $^{2}$} & Indian & Pakistani & Bangladeshi & Indian & Pakistani & Bangladeshi \\
\hline Remittances $^{1}$ & 1001 & 1103 & 1050 & 1559 & 1817 & 1486 \\
Income (gross monthly) $^{1}$ & 2010 & 1808 & 1615 & 1784 & 1206 & 1286 \\
Age of remitters $^{1}$ & 38.9 & - & - & 39 & 35 & 37 \\
Sending regular remittances $^{2}$ & 16 & 18 & 17 & 38 & 57 & 56 \\
Sending remittances to parents $^{2}$ & 35 & 46 & 30 & 53 & 67 & 48 \\
Sending remittances to children $^{2}$ & 5 & 3.6 & 0 & 3.7 & 4.5 & 0 \\
Married $^{3}$ & 33 & 49 & 52 & 67 & 62 & 84 \\
Muslim $^{3}$ & 15 & 93 & 91 & 7.3 & 99 & 99 \\
Owner occupied $^{3}$ & 50 & 56 & 49 & 46 & 32 & 59 \\
University degree $^{3}$ & 32 & 20 & 18 & 82 & 72 & 63 \\
Full time employee $^{3}$ & 81 & 66 & 52 & 59 & 60 & 77 \\
Part time employee $^{3}$ & 19 & 34 & 48 & 19 & 12 & 11 \\
Self employed $^{3}$ & 14 & 22 & 13 & 17 & 26 & 11 \\
Retired $^{3}$ & 7.7 & 7.5 & 6.8 & 5.0 & 2.0 & 0.0 \\
\hline
\end{tabular}

1. Boon (2006); 2. Clark and Drinkwater (2007); 3. Manchester City Council (2001). Sources 1 and 2 use national, 3 uses local data.

Table 3. Full Sample Summary Statistics, N. 691

\begin{tabular}{|c|c|c|c|c|}
\hline Variable & Mean & Median & Variable & Percentage of Respondents \\
\hline Remittances amount (annual) & 1672 & 1500 & Fulltime employment $^{\mathrm{d}}$ & 84 \\
\hline Income (monthly gross) & 1378 & 1250 & Female & 10 \\
\hline Recipient's income (monthly gross) & 238 & 150 & Married & 68 \\
\hline Age & 36.5 & 1 & Muslim & 74 \\
\hline Education level $^{\mathrm{a}}$ & 2.94 & 35 & UK citizen & 37 \\
\hline Duration of residency in UK (years) & 12.4 & 3 & Permanent resident & 25 \\
\hline Number of children in UK & 1.29 & 7 & Rural background & 23 \\
\hline Number of siblings in UK & 0.89 & 1 & Spouse in UK & 84 \\
\hline Frequency of visits to home country ${ }^{b}$ & 3.47 & 0 & Parents in UK & 18 \\
\hline Importance of remittances for consumption ${ }^{\mathrm{c}}$ & 0.77 & 3 & Remittances sent to spouse/children & 11 \\
\hline Importance of remittances for saving ${ }^{\mathrm{c}}$ & 0.25 & 1 & Remittances sent to aunt/uncle/cous. & 20 \\
\hline Importance of remittances for land ${ }^{\mathrm{c}}$ & 0.10 & 0 & Remittances sent to siblings & 28 \\
\hline Importance of remittances for education ${ }^{\mathrm{c}}$ & 0.19 & 0 & Remittances sent to parents & 59 \\
\hline \multirow[t]{3}{*}{ Importance of remittances for loans ${ }^{c}$} & 0.07 & 0 & Own accommodation & 42 \\
\hline & & & Fixed assets in $\mathrm{HC}$ & 88 \\
\hline & & & Informal remittances & 65 \\
\hline
\end{tabular}

a/Education level: 2: A level; 3: university; 4 postgraduate; b/ high values refer to low frequency of visit, i.e. 1: every 3 months, 3: yearly c/ higher values indicate higher level of importance; d/Full time employment includes full time employees and self employed. 
Table 4. Summary Statistics by Country of Origin

\begin{tabular}{lccclccc}
\hline & Pakistan & India & Bangladesh & Pakistan & India & Bangladesh \\
& N: 346 & N:191 & N: 153 & N: 1916 & N: 153 \\
\hline & Mean & Mean & Mean & Variables & percent & percent & percent \\
Remittances (annual) & 1817 & 1559 & 1486 & Fulltime employment & 87 & 76 & 89 \\
Income (monthly gross) & 1206 & 1784 & 1286 & Female & 6 & 23 & 5 \\
Recipient's income & 254 & 290 & 156 & Married & 62 & 67 & 84 \\
Age & 35 & 39 & 37 & Muslim & 28 & 37 & 99 \\
Education & 2.92 & 3.20 & 2.64 & UK citizen & 27 & 23 & 22 \\
Duration of residency in UK & 10.31 & 14.02 & 15.10 & Permanent residency & 21 & 12 & 39 \\
Number of children in UK & 1.18 & 1.06 & 1.80 & Rural origin & 47 & 60 & 85 \\
Number of siblings in UK & 0.69 & 0.45 & 1.88 & Spouse in UK & 16 & 11 & 31 \\
Frequency of visits to HC & 3.39 & 3.37 & 3.75 & Parents in UK & 20 & 5 & 1 \\
Imp. Of rem. For consumption & 0.86 & 0.59 & 0.78 & Rem. sent to spouse/children & 11 & 14 & 41 \\
Imp. of rem. for saving & 0.29 & 0.19 & 0.23 & Rem. sent to cous./unc./aunt. & 32 & 13 & 39 \\
Imp. of rem. for land & 0.06 & 0.04 & 0.27 & Rem. sent to siblings & 67 & 53 & 48 \\
Imp. of rem. for education & 0.21 & 0.11 & 0.24 & Rem. sent to parents & 32 & 46 & 59 \\
Imp. of rem. for loans & 0.04 & 0.15 & 0.06 & Own accommodation & 88 & 87 & 89 \\
& & & & Fixed assets in HC & &
\end{tabular}

Source: Authors' data and calculations.

Note: See Table 2 for the description of some of the variables. HC stands for home country

Table 5. Summary Statistics for Permanent and Temporary Migrants

\begin{tabular}{|c|c|c|c|c|c|c|c|}
\hline & & & $\begin{array}{r}\mathrm{F} \\
\mathrm{N} \\
\end{array}$ & & & $\begin{array}{l}\text { Temp } \\
\mathrm{N}: 259 \\
\end{array}$ & $\begin{array}{l}\text { Perm } \\
\mathrm{N}: 432 \\
\end{array}$ \\
\hline & Mean & Median & Mean & Median & & percent & percent \\
\hline Remittances amount (annual) & 1805 & 1500 & 1592 & 1500 & Full time employment & 76 & 89 \\
\hline Income (monthly gross) & 1156 & 750 & 1511 & 1250 & Female & 10 & 10 \\
\hline Recipient's income (monthly gross) & 280 & 250 & 208 & 150 & Married & 41 & 84 \\
\hline Age & 29.53 & 28 & 40.64 & 39 & Muslim & 70 & 76 \\
\hline Education level & 3.32 & 4 & 2.70 & 3 & UK citizen & 0 & 60 \\
\hline Time spent in the UK & 3.10 & 2.5 & 18.16 & 15 & Rural & 20 & 24 \\
\hline Number of children in UK & 0.20 & 0 & 1.94 & 2 & Spouse in UK & 25 & 79 \\
\hline Number of siblings in UK & 0.13 & 0 & 1.34 & 0 & Parents in UK & 2 & 28 \\
\hline Frequency of visits to home country & 3.30 & 3 & 3.55 & 3 & Rem. sent to spouse & 15 & 5 \\
\hline Imp. of rem. for consumption & 0.75 & 1 & 0.78 & 1 & Rem. sent to children & 3 & 4 \\
\hline Imp. of rem. for saving & 0.33 & 0 & 0.20 & 0 & Rem. sent to siblings & 20 & 33 \\
\hline Imp. of rem. for land & 0.03 & 0 & 0.14 & 0 & Rem. sent to parents & 84 & 45 \\
\hline Imp. of rem. for education & 0.20 & 0 & 0.18 & 0 & Own accommodation & 8 & 63 \\
\hline Imp. of rem. for loans & 0.16 & 0 & 0.02 & 0 & Fixed assets in $\mathrm{HC}$ & 91 & 85 \\
\hline
\end{tabular}

Source: Authors' data and calculations.

Note: See Table 2 for the description of some of the variables. 
a. Full Sample

Figure 1. Patterns of Remittances According to the Key Variables

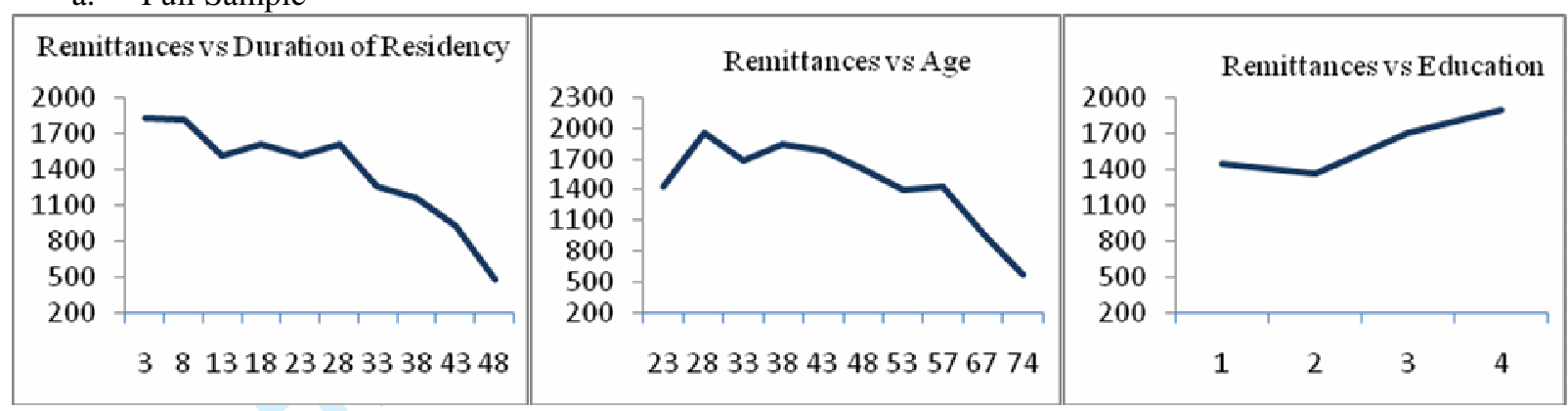

b. Indian Community

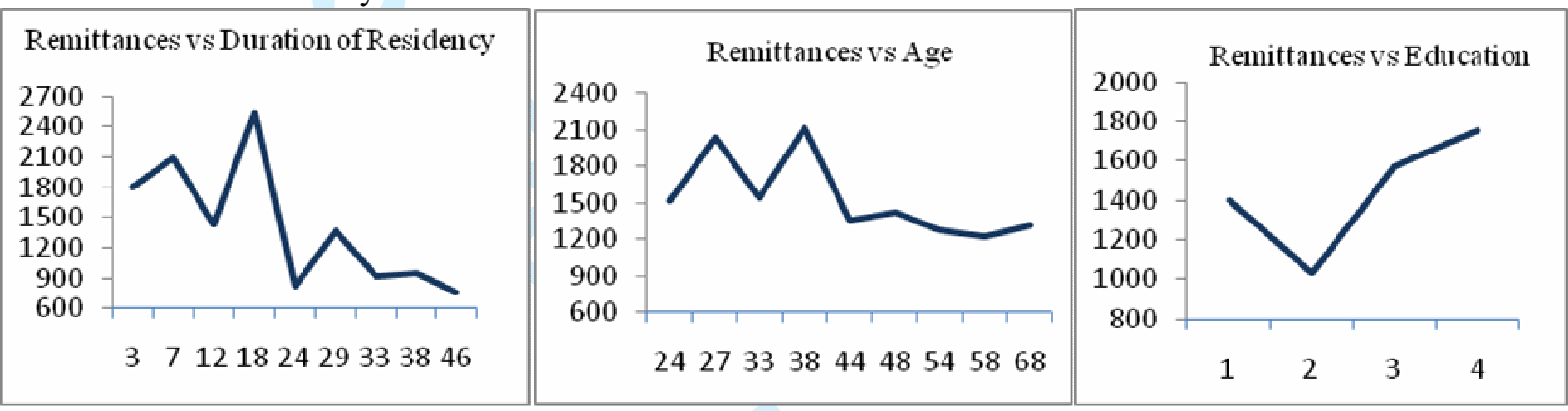

c. Pakistani Community

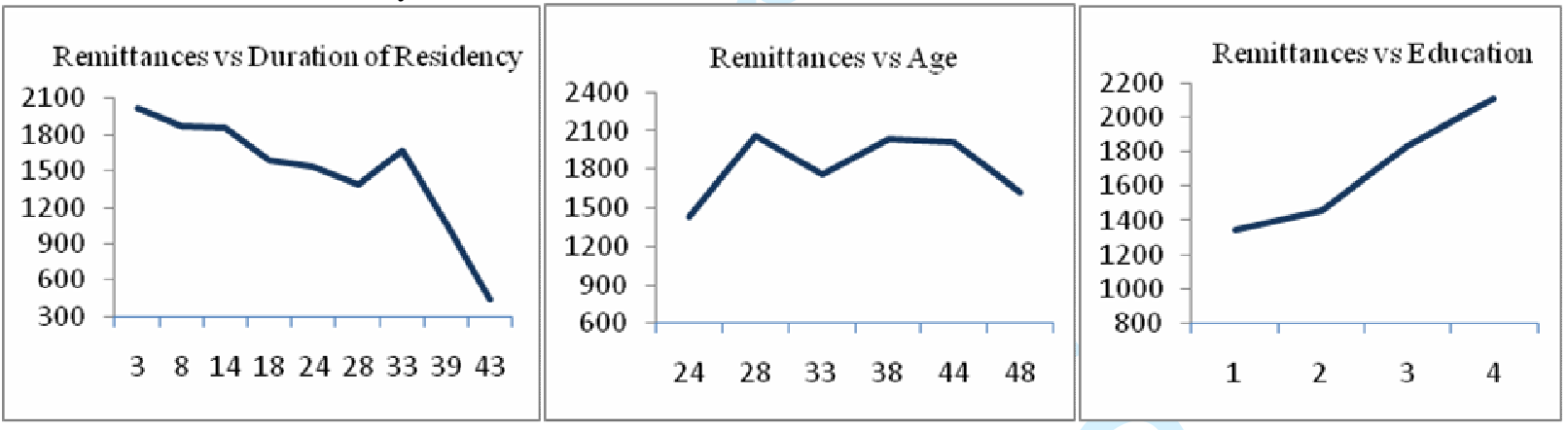

d. Bangladeshi Community

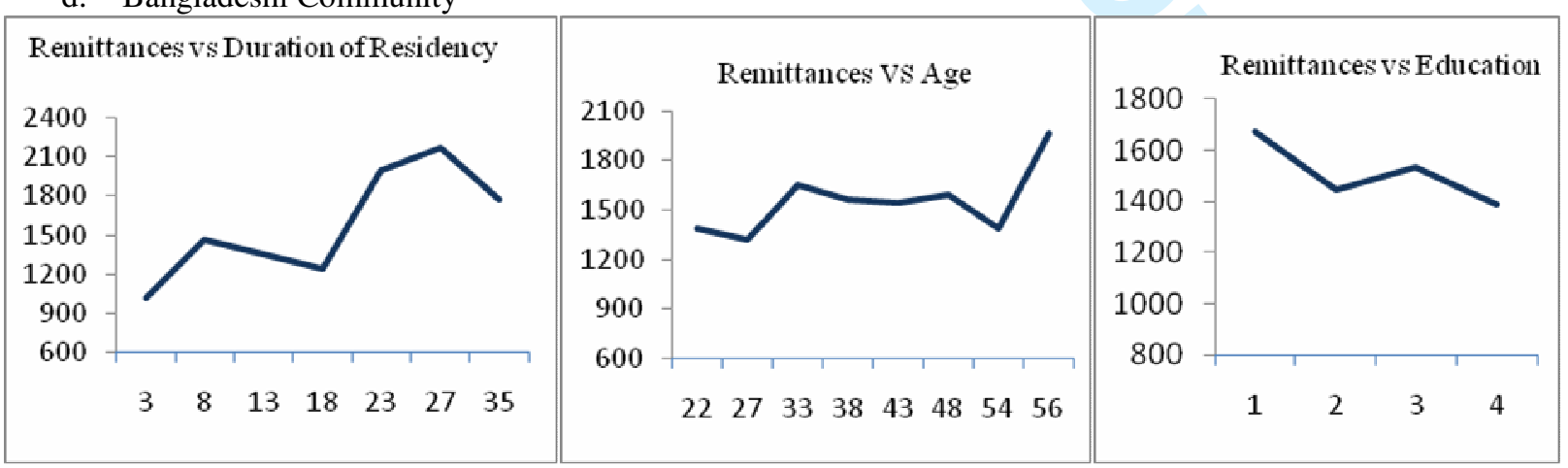

Source: Authors' data and calculation. Notes: Lines indicate changes in remittances against the respective variables. 
Table 6. OLS and SUR Regression of Log of Remittances

\begin{tabular}{|c|c|c|c|c|c|c|}
\hline & $\begin{array}{c}\text { Basic } \\
\text { Variables }\end{array}$ & $\begin{array}{c}\text { Rootedness } \\
\text { in UK }\end{array}$ & $\begin{array}{c}\text { Linkages } \\
\text { to HC }\end{array}$ & $\begin{array}{c}\text { Recipient's } \\
\text { Characteristics }\end{array}$ & $\begin{array}{c}\text { Use of } \\
\text { Remittances }\end{array}$ & SUR \\
\hline Log income & $\begin{array}{c}0.609 \\
(7.66) * * *\end{array}$ & $\begin{array}{c}0.770 \\
(9.51)^{* * * *}\end{array}$ & $\begin{array}{c}0.760 \\
(9.25)^{* * * *}\end{array}$ & $\begin{array}{c}0.758 \\
(9.35) * * *\end{array}$ & $\begin{array}{c}0.798 \\
(10.09) * * *\end{array}$ & $\begin{array}{c}0.780 \\
(10.25)^{* * * *}\end{array}$ \\
\hline Fulltime employment & $\begin{array}{c}0.304 \\
(3.32)^{* * * *}\end{array}$ & $\begin{array}{c}0.254 \\
(2.85)^{* * *}\end{array}$ & $\begin{array}{c}0.195 \\
(2.09)^{* *}\end{array}$ & $\begin{array}{c}0.194 \\
(2.09)^{* *}\end{array}$ & $\begin{array}{c}0.196 \\
(2.12)^{* *}\end{array}$ & $\begin{array}{c}0.195 \\
(2.13)^{* *}\end{array}$ \\
\hline Age bracket ${ }^{a}$ & $\begin{array}{c}-0.170 \\
(4.39)^{* * * *}\end{array}$ & $\begin{array}{r}-0.078 \\
(1.44)\end{array}$ & $\begin{array}{l}-0.063 \\
(1.16)\end{array}$ & $\begin{array}{l}-0.087 \\
(1.53)\end{array}$ & $\begin{array}{l}-0.076 \\
(1.35)\end{array}$ & $\begin{array}{l}-0.066 \\
(1.30)\end{array}$ \\
\hline Education & $\begin{array}{c}0.121 \\
(3.11)^{* * *}\end{array}$ & $\begin{array}{c}0.066 \\
(1.67)^{*}\end{array}$ & $\begin{array}{c}0.068 \\
(1.71)^{*}\end{array}$ & $\begin{array}{c}0.074 \\
(1.85)^{*}\end{array}$ & $\begin{array}{c}0.077 \\
(1.90)^{*}\end{array}$ & $\begin{array}{c}0.087 \\
(2.24)^{* *}\end{array}$ \\
\hline Married & $\begin{array}{c}-0.415 \\
(2.79) * * *\end{array}$ & $\begin{array}{l}-0.107 \\
(0.77)\end{array}$ & $\begin{array}{l}-0.101 \\
(0.70)\end{array}$ & $\begin{array}{l}-0.233 \\
(1.57)\end{array}$ & $\begin{array}{l}-0.210 \\
(1.46)\end{array}$ & $\begin{array}{l}-0.203 \\
(1.39)\end{array}$ \\
\hline Spouse from same ethnicity & $\begin{array}{c}0.417 \\
(2.83) * * *\end{array}$ & $\begin{array}{c}0.365 \\
(2.91)^{* * * *}\end{array}$ & $\begin{array}{c}0.343 \\
(2.56)^{* *}\end{array}$ & $\begin{array}{l}0.213 \\
(1.48)\end{array}$ & $\begin{array}{l}0.185 \\
(1.32)\end{array}$ & $\begin{array}{l}0.176 \\
(1.24)\end{array}$ \\
\hline Female & $\begin{array}{l}0.028 \\
(0.25)\end{array}$ & $\begin{array}{l}0.079 \\
(0.68)\end{array}$ & $\begin{array}{l}0.034 \\
(0.26)\end{array}$ & $\begin{array}{l}0.043 \\
(0.34)\end{array}$ & $\begin{array}{l}0.062 \\
(0.48)\end{array}$ & $\begin{array}{l}0.063 \\
(0.57)\end{array}$ \\
\hline Rural & $\begin{array}{l}0.119 \\
(1.58)\end{array}$ & $\begin{array}{l}0.096 \\
(1.30)\end{array}$ & $\begin{array}{c}0.158 \\
(2.09)^{* *}\end{array}$ & $\begin{array}{c}0.134 \\
(1.79) *\end{array}$ & $\begin{array}{c}0.143 \\
(1.96)^{*}\end{array}$ & $\begin{array}{c}0.141 \\
(1.85) *\end{array}$ \\
\hline Muslim & $\begin{array}{c}0.394 \\
(2.51)^{* *}\end{array}$ & $\begin{array}{c}0.347 \\
(2.30)^{* *}\end{array}$ & $\begin{array}{c}0.368 \\
(2.72) * * *\end{array}$ & $\begin{array}{c}0.305 \\
(2.27)^{* *}\end{array}$ & $\begin{array}{c}0.228 \\
(1.74) *\end{array}$ & $\begin{array}{l}0.213 \\
(1.09)\end{array}$ \\
\hline Permanent migrant ${ }^{\mathrm{b}}$ & & $\begin{array}{l}0.081 \\
(0.92)\end{array}$ & $\begin{array}{l}0.067 \\
(0.74)\end{array}$ & $\begin{array}{l}0.090 \\
(1.01)\end{array}$ & $\begin{array}{l}0.073 \\
(0.83)\end{array}$ & $\begin{array}{l}0.060 \\
(0.66)\end{array}$ \\
\hline Time spent in the UK & & $\begin{array}{c}-0.019 \\
(3.35)^{* * * *}\end{array}$ & $\begin{array}{c}-0.018 \\
(3.11) * * *\end{array}$ & $\begin{array}{c}-0.016 \\
(2.98)^{* * * *}\end{array}$ & $\begin{array}{c}-0.015 \\
(2.73)^{* * *}\end{array}$ & $\begin{array}{c}-0.014 \\
(2.93) * * *\end{array}$ \\
\hline Parents in the UK & & $\begin{array}{c}-0.274 \\
(2.12)^{* *}\end{array}$ & $\begin{array}{c}-0.291 \\
(2.32)^{* *}\end{array}$ & $\begin{array}{c}-0.278 \\
(2.10)^{* *}\end{array}$ & $\begin{array}{c}-0.303 \\
(2.29)^{* *}\end{array}$ & $\begin{array}{c}-0.294 \\
(2.44)^{* *}\end{array}$ \\
\hline Children in the UK & & $\begin{array}{l}0.051 \\
(1.43)\end{array}$ & $\begin{array}{l}0.031 \\
(0.85)\end{array}$ & $\begin{array}{l}0.048 \\
(1.27)\end{array}$ & $\begin{array}{l}0.046 \\
(1.24)\end{array}$ & $\begin{array}{l}0.046 \\
(1.53)\end{array}$ \\
\hline Spouse in the UK & & $\begin{array}{c}-0.475 \\
(4.00)^{* * * *}\end{array}$ & $\begin{array}{c}-0.443 \\
(3.45) * * *\end{array}$ & $\begin{array}{l}-0.231 \\
(1.62)\end{array}$ & $\begin{array}{l}-0.206 \\
(1.47)\end{array}$ & $\begin{array}{l}-0.207 \\
(1.63)\end{array}$ \\
\hline Siblings in the UK & & $\begin{array}{l}0.022 \\
(0.63)\end{array}$ & $\begin{array}{l}0.037 \\
(1.10)\end{array}$ & $\begin{array}{l}0.042 \\
(1.21)\end{array}$ & $\begin{array}{l}0.043 \\
(1.25)\end{array}$ & $\begin{array}{l}0.041 \\
(1.50)\end{array}$ \\
\hline Frequency of visits to home country ${ }^{\mathrm{c}}$ & & & $\begin{array}{l}-0.070 \\
(2.45)^{* *}\end{array}$ & $\begin{array}{c}-0.062 \\
(2.24)^{* *}\end{array}$ & $\begin{array}{l}-0.052 \\
(1.87)^{*}\end{array}$ & $\begin{array}{l}-0.048 \\
(1.89)^{*}\end{array}$ \\
\hline Remittances sent to spouse/children ${ }^{\mathrm{d}}$ & & & & $\begin{array}{c}0.533 \\
(3.98)^{* * *}\end{array}$ & $\begin{array}{c}0.507 \\
(3.76)^{* * * *}\end{array}$ & $\begin{array}{c}0.475 \\
(3.35)^{* * *}\end{array}$ \\
\hline Remittances sent to parents & & & & $\begin{array}{l}0.050 \\
(0.59)\end{array}$ & $\begin{array}{l}0.032 \\
(0.36)\end{array}$ & $\begin{array}{l}0.019 \\
(0.23)\end{array}$ \\
\hline Remittances sent to siblings & & & & $\begin{array}{l}0.024 \\
(0.33)\end{array}$ & $\begin{array}{l}0.017 \\
(0.23)\end{array}$ & $\begin{array}{l}0.009 \\
(0.12)\end{array}$ \\
\hline Remittances sent to aunt/uncle/cousin & & & & & $\begin{array}{l}0.008 \\
(0.07)\end{array}$ & $\begin{array}{l}0.003 \\
(0.03)\end{array}$ \\
\hline Remittances used for consumption ${ }^{\mathrm{e}}$ & & & & & $\begin{array}{l}0.116 \\
(1.14)\end{array}$ & $\begin{array}{c}0.220 \\
(2.51)^{* *}\end{array}$ \\
\hline Remittances used for savings & & & & & $\begin{array}{c}0.278 \\
(3.20)^{* * * *}\end{array}$ & $\begin{array}{c}0.445 \\
(5.11) * * *\end{array}$ \\
\hline Remittances used for land & & & & & $\begin{array}{c}0.338 \\
(2.73)^{* * *}\end{array}$ & $\begin{array}{c}0.532 \\
(4.26)^{* * * *}\end{array}$ \\
\hline Remittances used for education & & & & & $\begin{array}{l}0.100 \\
(1.00)\end{array}$ & $\begin{array}{l}0.163 \\
(1.64)\end{array}$ \\
\hline Remittances used for loan payments & & & & & $\begin{array}{c}0.283 \\
(1.95)^{*}\end{array}$ & $\begin{array}{c}0.332 \\
(2.29)^{* *}\end{array}$ \\
\hline Observations & 650 & 637 & 588 & 586 & 586 & 586 \\
\hline R-squared & 0.20 & 0.28 & 0.30 & 0.31 & 0.33 & \\
\hline
\end{tabular}

Robust t statistics in parentheses * significant at 10\%; ** significant at 5\%; *** significant at $1 \%$.

Note: Both country and district dummies are included in all regressions. Country dummies are not significant in any regressions. a/Age bracket: $1: 20-30 ; 2: 31-40 ; 3: 41-50 ; 4: 51$ and above; b/Permanent migrants are those who have UK citizenship or permanent residency in UK; c/Higher numbers refer to lower frequency of visits; $d$ /This is a dummy variable which takes on one if remittances are sent to the respective relative, zero otherwise; e/Importance of the use of remittances in different areas is measured as an index number, higher values refer to the higher level of importance. 
${ }^{1}$ Manchester is a multi-cultural city in the UK which has a very long relationship with South Asia. The growth of the city of Manchester from the mid- $18^{\text {th }}$ century onward went hand in hand with the arrival of people of many nationalities and ethnic groups. Many workers from South Asian countries (Bangladesh, Pakistan and India) came to Manchester from the 1950s to work in the mills.

${ }^{2}$ Our findings show that there is no difference between OLS/SUR and the Tobit analysis. Thus we reported the findings of OLS and SUR only.

${ }^{3}$ Only the individuals at and above 18 years of age are interviewed as we targeted those who are economically active and send remittances to their home country. This naturally raises the average age in our data.

${ }^{4}$ Those who have UK citizenship or permanent residence are referred to as permanent migrants while those who are on work permit/HSMP, short-term stay, student visa or asylum seekers are referred to as temporary migrants.

${ }^{5}$ The explanatory variables included in the SUR regression model of the five different uses of remittances are: $\log$ remittances, age bracket, education, rural background, time spent in the UK, permanent migration status, frequency of visits to home country, relationship of the recipients to the remitter, the country dummies and district dummies in the UK and home countries. We did not report the results of the regression analyses of the different uses of remittances, as their determinants are not the focus of this study.

\section{References}

Agarwal, R. and Horowitz, A.W (2002) Are international remittances altruism or insurance? Evidence from Guyana using multiple-migrant households. World Development, 30(11), pp. 20332044.

Ballard, R. (2003) The South Asian presence in Britain and its transnational connections, in Singh, H. and Vertovec, S. (eds) Culture and Economy in the Indian Diaspora, London: Routledge, pp. $197-222$.

Blue, S. (2004) State policy, economic crisis, gender, and family ties: determinants of family remittances to Cuba. Economic Geography, 80(1), pp. 63-82. 
Boon, M. (2006) BME remittance survey. Report for the Department for International Development. London: ICM Research.

Bollard, A., McKenzie, D., Morten, M. And Rapoport, H. (2009) Remittances and the Brain Drain Revisited: The Microdata Show That More Educated Migrants Remit More, IZA DP No. 4534

Brown, R.P.C. (1997) Estimating Remittance Functions for Pacific Island Migrants. World Development, 25(1), pp. 613-626.

Clark, K. and Drinkwater, S. (2007) An investigation of household remittance behaviour: evidence from the United Kingdom. The Manchester School, 75(6), pp. 717-741.

Dale, A. (2008) Migration, marriage and employment amongst Indian, Pakistani and Bangladeshi residents in the UK. Cathie Marsh Centre for Census and Survey Research Working Paper 2008-02.

DFID (2006) Sending money home? A survey of remittance products and services in the UK. Summary report prepared by Douglas Pearce \& Victoria Seymour, Department for International Development (DFID), United Kingdom.

\author{
Durand, J., W. Kandel, E. A. Parrado, and D.S. Massey (1996) International migration and \\ development in Mexican communities, Demography, 33 (2), pp. 249-264.
}


Dustmann, C. and Mestres, J. (2010) Remittances and temporary migration. Journal of Development Economics, 92 (1), pp. 62-70.

Funkhouser, E. (1995) Remittances from international migration: A comparison of El Salvador and Nicaragua. The Review of Economics and Statistics, 77(1), pp. 137-46.

Glytsos, N. P. (1997) Remitting behaviour of 'temporary' and 'permanent' migrants: the case of Greeks in Germany and Australia. Labour, 11(3), pp. 409-435.

Johnson, G. E and Whitelaw, W.E. (1974) Urban-rural income transfers in Kenya: an estimatedremittances function. Economic Development and Cultural Change, 22(3), pp. 473-79.

Knowles, J. and Anker, R. (1981) An analysis of income transfers in a developing country: the case of Kenya. Journal of Development Economics, 8(2), pp. 205-226.

Lianos, Theoodre P. (1997) Factors determining migrant remittances: the case of Greece. International Migration Review, 31(1), pp. 72-87.

Lucas, R.E.B. and Stark, O (1985) Motivations to remit: evidence from Botswana. Journal of Political Economy, 93(5), pp. 901-918.

Manchester City Council (2001) A Profile of the ethnic groups in Manchester. 2001 Census Topic Papers, 
http://www.manchester.gov.uk/downloads/file/750/m2_ethnic_groups_in_manchester_profile

Massey, D. S. and Basem, L. (1992) Determinants of savings, remittances, and spending patterns among Mexican Migrants to the United States. Sociological Inquiry, 62(2), pp.186-207.

Osili, U. O. (2001) Remittances and savings from international migration: theory and evidence using a matched sample. Unpublished Manuscript, Department of Economics Indiana UniversityPurdue University Indianapolis.

Poirine, B. (1997) A Theory of remittances as an implicit family loan arrangement. World Development, 25 (4), pp. 589-612.

Rapoport, H. and Docquier, F. (2005) The economics of migrants' remittances. IZA Discussion Papers 1531, Institute for the Study of Labour (IZA).

Sander, C. (2003) Migrant remittances to developing countries: a scoping study overview and introduction to issues for pro-poor financial services. Prepared for the UK Department of International Development (DFID), Bannock Consulting.

Seddon, D. (2004) South Asian remittances: Implications for development. Contemporary South Asia, 13 (4), pp. 403-420. 
Ulku, H. (2010) Remitting behaviour of Turkish migrants: evidence from household data in

Germany. Brook World Poverty Institute (BWPI) Working Paper No. 115, University of Manchester.

Vargas-Silva, C, Jha, S. and Sugiyarto, G. (2009) Remittances in Asia: Implications for the fight against poverty and the pursuit of economic growth, ADB Economics Working Paper No.182, Asian Development Bank.

World Bank (2008) Migration and Remittances Fact Book. World Bank: Washington, DC. 